\title{
Засоби фізичної терапії в корекції немоторних проявів хвороби Паркінсона
}

\author{
УДК 616.8-009.11
}

\section{А. Й. Лабінський, Г. Б. Лабінська}

Львівський національний університет ветеринарної медицини та біотехнологій імені С. З. Гжицького, Львів, Україна

Резюме. Мета. Вивчити ефективність розробленого комплексу фізичної терапії у хворих з немоторними проявами хвороби Паркінсона. Методи. Дослідження стану хворих 3 немоторними проявами хвороби Паркінсона за допомогою уніфікованої рейтингової шкали (UPDRS) та біохімічного дослідження ліпідного гомеостазу волосяних фолікул та волосся хворих з хроматографічним визначенням ліпідних фракцій до і після застосування розробленого авторами комплексу фізичної терапії. Результати. Проаналізовано результати обстеження та фізичного реабілітаційного лікування 32 пацієнтів з немоторними проявами хвороби Паркінсона. Доведено ефективність фізичної терапії в комплексі з гірудо-, апітерапією, мануальною та нутриціологічною корекцією у хворих з немоторними проявами хвороби Паркінсона за уніфікованою рейтинговою шкалою оцінки проявів паркінсонізму та дослідженням ліпідного гомеостазу. Висновки. Фізична терапія в комплексі з гірудо-, апітерапією, мануальною та нутриціологічною корекцією покращує стан хворих з немоторними проявами хвороби Паркінсона за уніфікованою рейтинговою шкалою оцінки проявів паркінсонізму та сприяє відновленню ліпідного гомеостазу, що дозволяє рекомендувати для ширшого впровадження вказану комплексну фізичну терапію немоторних виявів хвороби Паркінсона.

Ключові слова: хвороба Паркінсона, лікувальні фізичні вправи, нутриціологічна корекція, гірудотерапія, апітерапія, мануальна терапія, ліпідний гомеостаз.

\section{Physical therapy means in the correction of non-motor manifestations of Parkinson's disease}

\section{A. I. Labinskyi, H. B. Labinskaya}

S. Z. Gzhytsky Lviv National University of Veterinary Medicine and Biotechnology.

Abstract. Objective. To study the effectiveness of the developed physical therapy complex for patients with non-motor manifestations of Parkinson's disease. Methods. Investigation of the state of patients with non-motor manifestations of Parkinson's disease using the United Parkinson's Disease Rating Scale (UPDRS) and biochemical study of lipid homeostasis of hair follicles and hair of patients with chromatographic determination of lipid fractions before and after application of physical therapy complex developed by authors. Results. The results of examination and physical rehabilitation of 32 patients with non-motor manifestations of Parkinson's disease have been analyzed. The effectiveness of physical therapy in combination with hirudo-, apitherapy, manual and nutritional correction in patients with non-motor manifestations of Parkinson's disease according to the United Parkinson's Disease Rating Scale of lipid homeostasis has been proved. Conclusions. Physical therapy in combination with hirudo-, apitherapy, manual and nutritional correction improves the condition of patients with non-motor manifestations of Parkinson's disease according to United Parkinson's Disease Rating Scale (UPDRS) and promotes the restoration of lipid homeostasis. Therefore, it may be recommended for wider application.

Keywords: Parkinson's disease, therapeutic exercise, nutritional correction, hirudotherapy, apitherapy, manual therapy, lipid homeostasis. 
Постановка проблеми. Аналіз останніх досліджень i публікацій. Незважаючи на численні новітні схеми лікування, кількість хворих із хворобою Паркінсона та інвалідизація при вказаній патології останніми роками продовжує зростати [2, 12-14]. Особливу увагу заслуговують немоторні прояви хвороби Паркінсона (НПХП), які ускладнюють лікування на фооні зростання i помолодшання патології та важкості в терапевтичних підходах $[2,12,13]$. В доступній літературі достатньо описано вплив фрізичних вправ, фрізіотерапії та масажу на осіб при хворобі Паркінсона, подано практичні вказівки до занять лікувальною фрізичною культурою (ЛФК) для хворих на паркінсонізм, а також рекомендації щодо самообслуговування та тренування ходьби [1]. Однак немає досліджень, в яких розробляються та вивчаються комплекси фрізичної терапії саме для корекції немоторних виявів на ранніх стадіях хвороби Паркінсона, які можуть проявлятись з боку як м'язової системи, так і різних внутрішніх органів та маскувати основні симптоми захворювання.

Враховуючи сказане вище, нами розроблено оригінальний комплекс фрізичної реабілітації, в якому поєднують індивідуальні лікувальні фізичні вправи з нутриціологічними, гірудо-, апі- та мануальними методами фрізичної терапії для різноманітних немоторних виявів хвороби Паркінсона. Гірудотерапія відновлює реологічні властивості крові без побічних явищ, які $\epsilon$ у відомих антикоагулянтів, сприяючи значному посиленню мікроциркуляції у структурах екстрапірамідної нервової системи, яка уражається при хворобі Паркінсона [3]. Нутриціологічна корекція харчування спрямована на регуляцію амінокислотного метаболізму, ендотеліального метаболізму та нормалізацію роботи кишківника при шлунковокишкових немоторних виявах хвороби Паркінсона [14].

Зв'язок дослідження 3 науковими програмами, планами, темами. Робота виконана в межах НДР кафредри реабілітації та здоров'я людини Львівського національного університету ветеринарної медицини та біотехнологій імені С. З. Гжицького на тему «Особливості фрізичної терапії захворювань екстрапірамідної нервової системи та церебральних транзиторних ішемічних нападів і супутніх синдромів» (номер держреєстрації 0120U100690) запланованої до 2024 р.

Мета дослідження: вивчити та оцінити ефективність розробленого комплексу фрізичної терапії у хворих з немоторними проявами хвороби Паркінсона (з поєднанням спеціально розроблених гімнастичних лікувальних вправ, нутриціологічної, гірудо-, апі- та мануальної терапії).
Матеріал і методи дослідження: в роботі проаналізовано результати обстеження та фрізичного реабілітаційного лікування 32 пацієнтів 3 немоторними проявами хвороби Паркінсона 1,5-2 стадії по Хену-Яру, які знаходились на клінічних базах кафредри реабілітації та здоров'я людини Львівського національного університету ветеринарної медицини та біотехнологій імені С. 3. Гжицького [5]. Немоторні прояви у відібраної групи хворих спостерігались переважно у вигляді міалгій та артралгій, порушень мислення, настрою, мови, головного болю на фоні підвищеного артеріального тиску та шлунково-кишкових змін. Об'єктивний стан хворих оцінювали за уніфрікованою рейтинговою шкалою (UPDRS), зокрема першим та другим розділом, оскільки вони більше відображають НП ХП [6]. Для вивчення ліпідного гомеостазу у волосяних фолікулах та волоссі хворих застосовували хроматографрічну тонкошарову силікагельну методику визначення ліпідних фракцій, яка є модифікацією відомого методу Фолча [4].

ЛФК проводили протягом 10 тиж. поспіль у вигляді індивідуальних та групових занять тричі на тиждень. В оригінальному, розробленому нами комплексі терапевтичних вправ поєднували статичні вправи для релаксації м'язів кінцівок та хребта, особливо шийного та поперекового відділів, з динамічними вправами в аеробному режимі. При переході з релаксуючих статичних вправ на динамічні вправи з гантелями вагою 1-2 кг використовували петлі TRX для розвантаження суглобів. 50 \% вправ - це рухи в плечових та кульшових суглобах у горизонтальних площинах та ротаційному виконанні.

Під час проведення занять з ЛФК дотримувалися таких правил: вибирали вихідні положення, що забезпечують безболісне виконання фрізичних вправ для сприяння виявленню довільних та розвиненню наявних активних рухів; застосовували спеціальні вправи для розвитку рухливості у суглобах, прикладних навичок, зміцнення м'язів; поступово збільшували амплітуду рухів, використовуючи махові рухи 3 наростаючою амплітудою без обтяження, уникаючи різких рухів; не доводили напружені м'язи до стану вираженого стомлення, для цього чергували спеціальні вправи із загально розвиваючими. Рухи виконували із полегшених положень, при яких укорочується довжина важеля; використовували ковзні поверхні, застосовували гамачки, петлі TRX, що виключало необхідність переборювати вагу кінцівки. Застосовували корекцію постави симетричними і асиметричними вправами з проміжним контролем стану м'язової системи 3 допомого мануально-м'язового тестування. 
ТАБЛИЦЯ 1 - Показники стану хворих за уніфікованою шкалою UPDRS до і після застосування фізичної терапії $(n=32)$

\begin{tabular}{|l|c|c|c|}
\hline $\begin{array}{c}\text { Розділ за шкалою } \\
\text { UPDRS }\end{array}$ & $\begin{array}{c}\text { До проведення } \\
\text { фізичної } \\
\text { терапії }\end{array}$ & $\begin{array}{c}\text { Після } \\
\text { проведення } \\
\text { фізичної терапії }\end{array}$ & $\begin{array}{c}\text { Коефіцієнт } \\
\text { Стьюдента }\end{array}$ \\
\hline $\begin{array}{l}\text { I (мислення, пове- } \\
\text { дінка, настрій) }\end{array}$ & $9,87 \pm 0,24$ & $7,15 \pm 0,16$ & $\mathrm{~T}=6,5$ \\
\hline $\begin{array}{l}\text { II (повсякденна } \\
\text { активність) }\end{array}$ & $23,9 \pm 0,4$ & $20,4 \pm 0,3$ & $\mathrm{~T}=-9,2$ \\
\hline
\end{tabular}

Хворі харчувалися за принципами антиоксидантної насиченості раціону, достатньої кількості «баластних» речовин у раціоні, «вільного режиму» харчування з урахуванням біоритмів людини за настанням стійкого відчуття голоду та необхідності періодичного очисного (для очистки третього рівня травлення) голодування.

Гірудотерапію проводили, прикладаючи п'явок у зони верхніх полів Кренінга, паравертебрально на рівні першого, третього, сьомого шийних хребців та в проекції foramen magnum посередині.

Апітоксинотерапію проводили за схемою (поступові нарощування по одному бджоловжаленню через день по паравертебральних точках), після постановки біоадаптогенних проб на відсутність ідіосинкразії.

Мануальну терапію здійснювали після постізометричної релаксації та пневмовакуумного масажу у вигляді м'якої мобілізації та маніпуляції в шийному та поперековому відділах хребта.

Результати дослідження та їх обговорення. Після проведеної фрізичної терапії стан хворих значно покращився. У більшої частини хворих зникли, а у решти стали менш інтенсивними міалгії та артралгії, порушення мислення, покращився настрій, нормалізувався артеріальний
Спортивна медицина і фізична реабілітація, № 1, 2020

тиск. Зміни показників об'єктивного стану хворих після проведеного лікування за уніфрікованою шкалою UPDRS показано в таблиці 1.

Як видно з таблиці 1, після проведеної комплексної фрізичної терапії загальний бал по розділу «мислення, поведінка, настрій» оціночної шкали та розділу «повсякденна активність» статистично достовірно зменшився, що свідчить про покращення їх стану у вигляді зменшення усіх проявів немоторних фрлуктуацій.

Ліпідний гомеостаз вивчали у хворих до та після застосування фрізичної терапії і у здорових осіб (20 практично здорових осіб без шкідливих звичок). У контрольній групі показники фрракцій ліпідів у волоссі розподілились таким чином, як показано на рисунку 1.

Показники ліпідних фрракцій до застосування фрізичної терапії та після її проведення у хворих з немоторними проявами ХП наведено в таблиці 2.

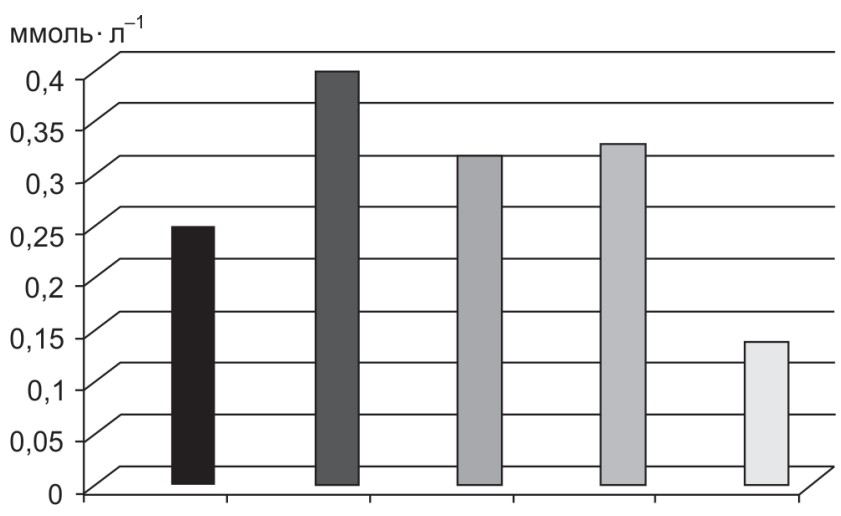

Рисунок 1 - Вміст фракцій ліпідів у волоссі здорових осіб (контрольна група, $\mathrm{n}=32$ ):

- полярні ліпіди; $\square$ - ефіри холестерину;

$\square$ - вільні жирні кислоти; $\square$ - триацилгліцириди;

$\square-$ вільний холестерин

ТАБЛИЦЯ 2 - Вміст фракцій ліпідів у волоссі хворих НПХП до і після застосування фізичної терапії $(\mathbf{n}=32)$

\begin{tabular}{|c|c|c|c|c|}
\hline Фракції ліпідів & Кількість ммоль $\cdot \pi^{-1}$ & $p$ & Коефіцієнт Стьюдента & Коефіцієнт кореляції \\
\hline $\begin{array}{l}\text { Полярні ліпіди } \\
\text { до фізичної терапії } \\
\text { після фрізичної терапії }\end{array}$ & $\begin{array}{l}0,18 \pm 0,01 \\
0,23 \pm 0,01\end{array}$ & $<0,05$ & 2,36 & 0,61 \\
\hline $\begin{array}{l}\text { Ефіри холестерину } \\
\text { до фрізичної терапії } \\
\text { після фрізичної терапії }\end{array}$ & $\begin{array}{l}0,28 \pm 0,01 \\
0,32 \pm 0,01\end{array}$ & 0,05 & 2,11 & 0,49 \\
\hline $\begin{array}{l}\text { Вільні жирні кислоти } \\
\text { до фрізичної терапії } \\
\text { після фрізичної терапії }\end{array}$ & $\begin{array}{c}0,1 \pm 0,01 \\
0,12 \pm 0,01\end{array}$ & $>0,05$ & 0,78 & 0,86 \\
\hline $\begin{array}{l}\text { Триацил гліцериди } \\
\text { до фізичної терапії } \\
\text { після фрізичної терапії }\end{array}$ & $\begin{array}{l}0,11 \pm 0,006 \\
0,09 \pm 0,005\end{array}$ & $<0,05$ & $-2,12$ & 0,56 \\
\hline $\begin{array}{l}\text { Вільний холестерин } \\
\text { до фрізичної терапії } \\
\text { після фрізичної терапії }\end{array}$ & $\begin{array}{c}0,37 \pm 0,01 \\
0,14 \pm 0,1\end{array}$ & $<0,05$ & $-1,96$ & 0,26 \\
\hline
\end{tabular}


Показник полярних ліпідів, як видно із таблиці, при ХП у волоссі хворих значно зріс, що підтверджує статистичну вірогідність збільшення кількості полярних ліпідів у волоссі групи хворих після застосування фозичної терапії ( $<0,05)$. При проведенні кореляційного аналізу між групами хворих до та після фрізичної терапії відмічається високий ступінь однонаправленості змін, про що свідчить коефіцієнт кореляції. Вільні жирні кислоти та ефріри холестерину зазнали дуже незначних змін, значення яких не $\epsilon$ статистично достовірним ( $p \geq 0,05)$. Триацилгліцериди зазнали вже більш значних змін, які є статистично достовірними ( $<0,05)$. Значення фракції вільного холестерину статистично достовірно зменшилось після проведення фрізичної терапії.

Артеріальний тиск знизився у всіх хворих після фрізичної терапії в середньому на $20 \pm 2,2$ одиниць систолічний, та на $15 \pm 1,5$ діастолічний.

При дослідженні ліпідного гомеостазу ріст фрракції полярних ліпідів свідчить про відновлення структури клітинних мембран, у тому числі екстрапірамідної системи головного мозку, основною складовою яких вони є. Статистично достовірне зменшення фрракції вільного холестерину у волоссі хворих після проведеної фрізичної терапії може означати зменшення рівня атерогенезу та процесів перекисного окиснення ліпідів, у яких саме вільний холестерин відіграє головну роль $[9,10]$. Такі позитивні зміни, можливо, відбулись за рахунок впливу ЛФК і антиоксидантних

\section{Література}

1. Агафонова О, Білянський О, Єфімова С. Особливості фізичної реабілітації при хворобі Паркінсона. Спортивна наука України. 2014; 3 (61): 7-11.

2. Карабань IM, Карасевич НВ. Сучасні аспекти діагностики та медикаментозної терапії хвороби Паркінсона [Modern aspects of diagnosis and medical therapy of Parkinson's disease]. Журн. неврології ім. Б. М. Маньковського. 2015; 1: 50-57.

3. Савинов ВА. Гирудотерапевтический экскурс в кардиологию: [Hirudotherapeutic excursion in cardiology]. Издательство «Янус-К». 2013. 175 с

4. Овчинникова СИ. Качественный и количественный анализ липидов, углеводов, витаминов 2-е изд. Мурманск, МГТУ. 2010; 125 с.

5. Шашкин ЧС, Шпеков АС, Калиев АБ, Джамантаева БД, Комаров жИ. Болезнь Паркинсона в нейрохирургической практике [Parkinson's disease in neurosurgery]. Нейрохирургия и неврология Казахстана. 2013; 1 (30): 17-22.

6. Goetz CG, Poewe W, Rascol O, et al. The Unified Parkinson's Disease Rating Scale (UPDRS): Status and Recommendations. Movement Disorder Society Task Force on Rating Scales for Parkinson's Disease. Movement Disorders. 2003; 18, 7: 738-750.

7. Niederer D, Vogt L, Wilke J, et al. Age-related cutoffs for cervical movement behaviour to distinguish chronic idiopathic neck pain patients from unimpaired subjects. European Spine Journal. 2015; 24, 3: 493-502.

lajboxnet@gmail.com та інші харчових речовин нутріциологічної корекції, біоактивних фрракцій секрету алотрофічних залоз п'явок на ліпопротеїнові комплекси цитопротоплазматичних мембран тканин $[1,3,9,10]$. $€$ дані про вплив секрету алотрофрічних залоз п'явок медичних не тільки на реологію крові, а й на пришвидшення репаративних процесів у тканинах [3]. Певну роль у покращенні стану хворих та структури тканин відіграло посилення мозкового кровообігу у вертебробазилярному басейні внаслідок занять лікувальною гімнастикою та мануальною терапією, спрямованих на усунення явищ остеохондрозу в шийно-грудному відділі хребта [7]. Можна припустити, що покращення стану хворих, зниження артеріального тиску та певна нормалізація ліпідного гомеостазу, відбулись під впливом розробленої нами комплексної фрізичної терапії.

\section{Висновки}

1. Реєстровані зміни в покращенні об'єктивного стану хворих свідчать про ефективність застосованої фрізичної терапії.

2. Фізична терапія в комплексі з гірудо-, апітерапією, мануальною та нутріциологічною корекцією покращує стан хворих з немоторними виявами хвороби Паркінсона за уніфікованою рейтинговою шкалою оцінки проявів паркінсонізму та сприяє відновленню ліпідного гомеостазу, що дозволяє рекомендувати для ширшого впровадження вказану комплексну фрізичну терапію немоторних проявів хвороби Паркінсона.

8. Poewe W, Mahlknecht P. Двигательные расстройства: новые открытия в области механизмов заболевания и его лечения [Motor disorders: new discoveries in mechanisms of disease and its treatment]. Ланцет. Неврология. Украинское издание. 2014; 4-5: 12-14.

9. Polumbryk M, Ivanov S, Polumbryk O. Antioxidants in food systems Mechanism of action. Ukr. J. Food Sci. 2013; 1: 15-40.

10. Prochazkova D, Bousova I, Wilhelmova N. Antioxidant and prooxidant properties of flavonoids. Fitoterapia. 2011; 82: 513-523.

11. Quinn N, Bhatia K, Brown P, et al. Movement Disorders. Neurology: A Queen Square Textbook. - Oxford : Blackwell Publishing Ltd, 2009. - P. 155187.

12. Rahman S, Griffin HJ, Quinn NP, et al. Quality of life in Parkinson's disease: the relative importance of the symptoms. Mov. Disord. 2008; 23 (10):1428-1434

13. Ray Chaudhuri K, Rojo JM, Schapira $A H$, et al. A proposal for acomprehensive grading of Parkinson's disease severity combining motor and non-motor assessments: meeting an unmet need. PLoS One. 2013; 8 (2): e57221.

14. Sauerbier A, Jenner $P$, Todorova A, Ray Chaudhuri K. Non motor subtypes and Parkinson's disease. Lancet Neurology. 2016; 365: 162-166.

Надійшла 20.02.2020 